\title{
STABILITY-INDICATING METHODS FOR THE DETERMINATION OF GEMIFLOXACIN IN PRESENCE OF ITS ACID DEGRADATION PRODUCT(S)
}

\author{
Ezzat M.Abdel-Moety ${ }^{1}$, Amr M. Badawey², Hebatallah M. Essam³ ${ }^{3}$ Fatma M. \\ AboulAlamain ${ }^{* 4}$.
}

${ }^{1}$ Cairo University, Faculty of Pharmacy, Analytical Chemistry Department, Kasr el Aini St, Cairo, Egypt. eamoety@gmail.com

${ }^{2}$ Future University, Faculty of Pharmaceutical Sciences and Pharmaceutical Industries, Pharmaceutical Chemistry Department, 1211, Cairo, Egypt. amrbadawey2014@hotmail.com

${ }^{3}$ Cairo University, Faculty of Pharmacy, Analytical Chemistry Department, Kasr el Aini St, Cairo, Egypt. Heba_essam80@hotmail.com

${ }^{4}$ The Holding Company for Biological Products \& Vaccines VACSERA, Giza, Egypt. Corresponding author E-mail: falamine2004@yahoo.com

\begin{abstract}
Brilliant, valid and simple five UV spectrophotometricstability indicating techniques are adopted for the determination of Gemifloxacin (GEM) in presence of its acid degradation products over a concentration range of $2-12 \mu \mathrm{m} \mathrm{mL} \mathrm{L}^{-1}$. The first method is an application of the first derivative ( $\left.{ }^{1} D\right)$ spectrophotometry, that allows the determination of GEM without interference of its acid degradation products at zero crossing wavelength $(254.6 \mathrm{~nm})$. The second method depends on the first-derivative of the ratio spectra spectrophotometry ( $\left.{ }^{1} D D\right)$ for determination of GEM in presence of its acid degradation products at a maximum of $273.0 \mathrm{~nm}$ and a minimum of $284.0 \mathrm{~nm}$, While the third dual wavelength method offers a superior stability indicating procedures for the determination of GEM in the zero order spectra at the wavelength pair of $271.8 \mathrm{~nm}$ and $325.0 \mathrm{~nm}$. The fourth method is the ratio difference one, with the advantages of minimal data processing and wide range of application. It is applied for the analysis of intact drug in presence of its acid degradation products by measuring the difference in the peak amplitude at the ratio spectra at $355.0 \mathrm{~nm}$ and $270.0 \mathrm{~nm}$. The last method is based on the quantification of GEM through the bivariate calibration at $255.0 \mathrm{~nm}$ and $277.0 \mathrm{~nm}$ by adopting simple mathematic algorithm that provides simplicity and rapidity.
\end{abstract}

Keywords: Gemifloxacin; first derivative; derivative ratio;dual wave length; bivariate calibration; ratio difference.

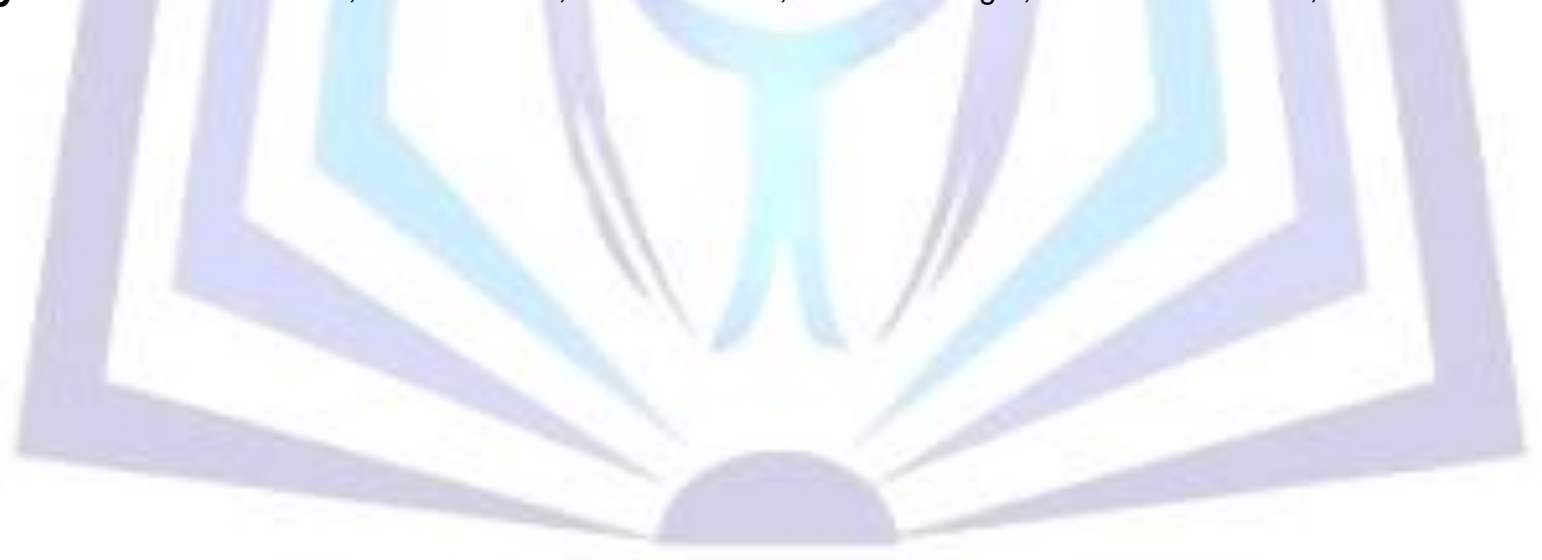

\section{Council for Innovative Research}

Peer Review Research Publishing System

\section{Journal: Journal of Advances in Chemistry}

Vol 11, No. 6

editorjaconline@gmail.com, www.cirjac.com 


\section{INTRODUCTION}

Gemifloxacin; chemically is 7-[(3-(Aminomethyl)-4-(methoxyimino)-1-pyrrolidinyl]-1-cyclopropyl-6-fluoro-1,4-dihydro-4-oxo1,8-naphthyridine-3-carboxylic acid ${ }^{[1]}$, Figure (1). It is an oral broad-spectrum third generation fluoroquinolones antibacterial agent used in the treatment of acute bacterial exacerbation of chronic bronchitis and mild-to-moderate pneumonia. It is indicated for the treatment of respiratory and urinary tract infection ${ }^{[2]}$. Gemifloxacin (GEM) is rapidly absorbed from the gastrointestinal tract with an absolute bioavailability of about $71 \%$. A peak plasma concentration is occurring 0.5 to 2 hours after an oral dose. It undergoes limited hepatic metabolism and has an elimination half -life of about 7 hours. It is excreted as unchanged drug and metabolites in the faeces and urine ${ }^{[3]}$.

Several analytical techniques were widely described for the analysis of GEM. Some spectroscopic methods with different approaches including colorimetric ${ }^{[4-7]}$, and fluorimetric ${ }^{[8]}$ procedures were developed. GEMcan also be determined byLCtandem MS ${ }^{[8-12]}$ and thin layer chromatography ${ }^{[13]}$. Different high performance liquid chromatographic [HPLC] methods were used for analysis of GEM in variable sample matrices ${ }^{[14-25]}$. But according to the literatures in hands, there is no direct stability indicating spectrophotometric method was developed for GEM quantification.

\section{EXPERIMENTAL}

\subsection{Instrumentation}

Dual-beam UV-visible spectrophotometer, UV-1650 PC (Shimadzu) with matched $1 \mathrm{~cm}$ quartz cells, connected to an IBM compatible personal computer (PC), software is UV Probe version 2.21

\subsection{Materials and reagents}

- Gemifloxacin (GEM) pure sample,HIKMA Pharma, Giza-Egypt. Its purity was assessed to be $99.61 \pm 0.579 \%(n=6)$ according to a reported spectrophotometric method ${ }^{[4]}$.

- Factive ${ }^{\circledR}$ tablets,each tablet claimed to contain426.39 mg gemifloxacin mesylate equivalent to $320 \mathrm{mg}$ gemifloxacin, batch No.(BN) 005 , manufactured by HIKMA Pharma S.A.E-Egypt, under license of LG life science ,Ltd, Seoul-Korea.

- Methanol: Spectroscopic grade (E. Merck, Darmstadt- FRG).

- Sodium hydroxide, 4M aqueous solution and hydrochloric acid, 3M aqueous solution (Adwic, Cairo-Egypt).

\subsection{Standard solutions}

\subsubsection{Standard solution of Gemifloxacin}

A standard stock solution of GEM was prepared by transferring accurately $100 \mathrm{mg}$ of pure drug into $100-\mathrm{mL}$ volumetric flask, dissolving in $20 \mathrm{~mL}$ methanol and then the volume was completed to the mark with the same solvent to provide standard stock solution containing $1 \mathrm{mg} \mathrm{mL}^{-1}$.

\subsubsection{Working solution of Gemifloxacin}

GEM working solution was prepared by transferring $10 \mathrm{~mL}$ of the standard stock solution into100-mL volumetric flask and then the volume was completed to the mark with methanol to obtain standard working solution containing $0.1 \mathrm{mg} \mathrm{mL}^{-1}$ of GEM, and then further dilution was applied to reach final concentration of $10 \mu \mathrm{g} \mathrm{mL}^{-1}$.

\subsubsection{Stock solution of acid degraded GEM}

Accurately weighed $100 \mathrm{mg}$ of pure GEM was transferred to a $250-\mathrm{mL}$ round bottomed flask and $25 \mathrm{ml}$ of $3 \mathrm{~N} \mathrm{HCL}$ was added, and then refluxed with continuous magnetic stirring for 10 hrs. The solution was neutralized to $\mathrm{pH} 7 \mathrm{with} 4 \mathrm{~N} \mathrm{NaOH}$, concentrated nearly to dryness and cooled to room temperature. The residue was dissolved with least amount of methanol, and then filtered, the filtrate was collected into $100 \mathrm{ml}$ measuring flask and the volume was made up with methanol. Complete acid degradation of GEM was confirmed by TLC -fractionation on silica gel F 254 plates using ethyl acetate : methanol : ammonia ( $8: 4: 3$ by volumes as a developing solvent, visualization was carried under UV -lamp $254.0 \mathrm{~nm}{ }^{[14]}$. Then the degradation products were elucidated by mass spectrometry.

Aliquot portion of this solution was diluted with distilled water to prepare working stock solution of $10 \mu \mathrm{gL}^{-1}$.

\subsection{Procedures}

\subsubsection{Construction of calibration curves}

Accurately measured volumes of intact GEM working solution $\left(0.1 \mathrm{mg} \mathrm{mL}^{-1}\right)$ were transferred into a series of $10-\mathrm{mL}$ volumetric flasks and diluted to the mark with methanol to obtain concentrations from 2 to $12 \mu \mathrm{gL}^{-1}$. These prepared concentrations were used to construct the calibration curve for each theory as follows: 


\subsubsection{For $D^{1}$ spectrophotometric method.}

The $D^{1}$ spectra of each solution was recorded using $\Delta \lambda=4$ and scaling factor $=20$. For determination of GEM in presence of its acid degradation products, calibration curve was obtained by plotting the peak amplitudes of $D^{1}$ at $254.6 \mathrm{~nm}$ (corresponding to zero-crossing of the degradation products) versus the corresponding drug concentrations, and regression equation was computed.

\subsubsection{For $\left(D^{1}\right)$ spectrophotometric method.}

The absorption spectra of these solutions were divided by the absorption spectrum of $8 \mu \mathrm{gL}^{-1}$ of the acid degradation products (as divisors). The obtained ratio spectra were then differentiated with respect to wavelength using $\Delta \lambda=4$ and scaling factor $=1$. The peak amplitudes at peak $273.0 \mathrm{~nm}$ and trough $284.0 \mathrm{~nm}$ were recorded for the determination of GEM in presence of its acid degradation products. The calibration curves representing the relationship between the measured amplitudes and the corresponding concentrations of the drug were constructed and the regression equations were computed.

\subsubsection{For dual wave length method.}

The Zero-order spectrum of each dilution was recorded against methanol as blank. The absorbance difference of GEM was measured between the selected wavelength pair $(271.8 \mathrm{~nm} \& 325.0 \mathrm{~nm})$ for each dilution separately, and then the obtained differences were plotted against the corresponding concentrations of the drug and the regression equation was then computed.

\subsubsection{For ratio difference spectrophotometric method:}

The zero order spectra of the prepared concentrations of GEM were divided by the spectra of $8 \mu \mathrm{mL} \mathrm{m}^{-1} \mathrm{GEM}$ acid degradation product, the difference in the peak amplitudes at the ratio spectra was measured at 355.0 and $270.0 \mathrm{~nm}(\triangle \mathrm{P})$ - Calibration graph relating $\triangle \mathrm{P}$ at the chosen wavelength couples to the corresponding concentrations of GEM was constructed, and the corresponding regression equation was computed.

\subsubsection{For bivariate spectrophotometric method.}

A concentration series of the acid degradation products was prepared as well. Accurately measured volumes from its working solution were transferred separately into a series of $10-\mathrm{mL}$ volumetric flasks and diluted to the mark with methanol to obtain concentrations from 2 to $12 \mathrm{\mu g} \mathrm{mL}^{-1}$. The Zero-order spectrum of each dilution was recorded against methanol as blank. The absorbance of GEM and its acid degradation products were measured at $255.0 \mathrm{~nm}$ and $277.0 \mathrm{~nm}$ for each dilution separately, and then the absorbance at the selected wavelengths were plotted against the corresponding concentrations and the regression equations were then computed.

\subsubsection{Laboratory prepared mixtures}

Laboratory synthetic mixtures containing GEM and different percentages of its degradation product were prepared by transferring aliquot portions $(1-9 \mathrm{~mL})$ of the GEM working solution in a concentration of $\left(10 \mu \mathrm{mL}^{-1}\right)$ into a series of 10 $\mathrm{mL}$ measuring flasks. Different portions of the acid degraded solution its concentration is $10 \mu \mathrm{g} \mathrm{mL} \mathrm{L}^{-1}$ were also added to prepare different mixtures containing $10-90 \%$ of the degradation products then the volumes were made up with methanol.

\subsubsection{Application to pharmaceutical preparation}

Ten Factive ${ }^{\circledR}$ tablets were powdered finely, a weight equivalent to $100 \mathrm{mg}$ GEM was transferred accurately into a 100$\mathrm{mL}$ volumetric flask and sonicated for 20 min with about $50 \mathrm{~mL}$ methanol, followed by filtration through filter paper then the volume was completed with methanol to $100 \mathrm{~mL}$. Further dilutions were applied with methanol in order to reach the linearity rang. The general procedures were followed and the concentration of GEM was calculated from its corresponding regression equations.

\section{RESULTS AND DISCUSSION}

The focus of the present work was to develop accurate, specific, and sensitive stability indicating methods for the determination of GEM in pure form and in pharmaceutical formulation in presence of its potential acid degradation products.

\subsection{Separation and identification of degradation products}

Accelerated stability studies were applied to GEM to explore its inherent stability characteristics and it was found that GEM is susceptible to hydrolysis under acidic conditions. The expected scheme of acid degradation of gemifloxacin may be illustrated as shown in Scheme (1).The structure of the acid-induced degradation products was confirmed using mass spectral analysis as shown in Figure (2).The zero-order absorption spectra of GEM and its acid degradation products show sever overlapping, Figure (3), which interferes with the direct determination of GEM. This problem suggested that these proposed methods are suitable method for the simultaneous determination of GEM in presence of its acid degradation products. 


\section{2. $D^{1}$ method:}

The obtained spectra showed good resolutions allowing clear determination of GEM at 254.6 nm without any contribution of its degradation products that show zero crossing at the selected wavelength, Figure (4). Linear calibration curves were obtained for the suggested method in concentration range of $\left(2-12 \mu \mathrm{g} \mathrm{mL}^{-1}\right)$. The regression equation was calculated and found to be:

${ }^{1} \mathrm{D}_{\mathrm{GEM}}=0.0585 \mathrm{C}+0.0142 \quad(\mathrm{r}=0.9997)$.

${ }^{1} \mathrm{D}$ : Peak amplitude of first derivative. C: Concentration $\left(\mu \mathrm{g} \mathrm{mL}{ }^{-1}\right), \mathrm{r}$ : Correlation Coefficient.

\section{3. ${ }^{1}$ DD method:}

${ }^{1}$ DDvalues showed good linearity and reproducibility at a peak $273.0 \mathrm{~nm}$ and a trough $284.0 \mathrm{~nm}$ without interference from its acid degradation products Figure (5). Linearity of the peak amplitudes of the ${ }^{1} \mathrm{DD}$ curves at both wavelengths was obtained in the range of $2-12 \mu \mathrm{g} \mathrm{mL}^{-1}$ and the regression equations were computed as shown below:
${ }^{1} \mathrm{DD}=0.0767 \mathrm{C}-0.0629$
$(r=0.9994)$
$(273.0 \mathrm{~nm})$
${ }^{1} \mathrm{DD}=0.1014 \mathrm{C}-0.0656$
$(r=0.9996)$
$(284.0 \mathrm{~nm})$

Where,

${ }^{1} \mathrm{DD}$ : peak amplitude of first derivative of the ratio spectra.

C : Concentration $\left(\mu \mathrm{g} \mathrm{mL}^{-1}\right), \quad r$ : Correlation coefficient.

\subsection{Dual wavelength method:}

Dual wavelength method copes with the level of interference when the spectra as strongly overlapped as shown in Figure (3), It uses the analytical signal data at two accurately selected wavelengths, thus appropriate selection, thus appropriate selection of wavelength pair is very important. To select the appropriate wavelength pair, the following principles were applied: at the selected wavelengths, the difference in analyte signals had to be linear while the difference in interferent signal is remaining zero with changing the concentration. In addition, the analytical signal obtained from a mixture of the analyte and the interferent should be equal to the sum of the individual signals of the two species. Also, the difference in absorbance due to the analyte signal at the two selected wavelengths should be as large as possible in order to reach good accuracy and sensitivity ${ }^{[26]}$

To optimize the method, different pairs of wavelengths were selected and tried to show zero absorbance difference for the GEM acid degradation products with maximum difference in absorbance due to GEM, $271.8 \mathrm{~nm}$ and $325.0 \mathrm{~nm}$ were selected for the determination of GEM, where the acid degradation product shows the same absorbance. A linear Calibration curve was obtained in the range $\left(2-12 \mu \mathrm{g} \mathrm{mL}^{-1}\right)$ relating the difference between the absorbance at the two selected wavelengths $271.8 \mathrm{~nm}$ and $325.0 \mathrm{~nm}$ to the corresponding drug concentrations in presence of acid degradation product and the regression equation was calculated and found to be:

$\Delta \mathrm{P}_{\mathrm{GEM}}=0.0581 \mathrm{C}-0.0253 \quad(\mathrm{r}=0.9998)$.

Where, $\Delta \mathrm{P}$ : Absorbance difference at the two selected wavelengths $(271.8$ and $325.0 \mathrm{~nm})$.

$$
\text { C : Concentration }\left(\mu \mathrm{g} \mathrm{mL}^{-1}\right), r \text { : Correlation coefficient. }
$$

\subsection{Ratio difference spectrophotometric method:}

A smart ratio-difference method has been developed recently with the advantages of minimal data processing and wide range of application, in addition to the advantages of ratio spectra manipulation ${ }^{[27]}$, Figure (6). The linear regression data for the calibration curve showed a good linear relationship over a concentration range of $2-12 \mu \mathrm{mL}^{-1}$ and the regression equation was computed and found to

$\Delta P=0.7113 \mathrm{C}+0.0927 \quad(r=0.9996)$. Where,

$\Delta \mathrm{P}$ : Absorbance difference at the two selected wavelengths.

C: Concentration $\left(\mu \mathrm{g} \mathrm{mL}^{-1}\right), \mathrm{r}$ : Correlation coefficient.

\subsection{Bivariate Calibration Method}

GEM was also determined and resolved from its acid degradation products by using bivariate calibration spectrophotometric method, which is based on a simple mathematical algorithm. The method has been successfully applied to resolve different binary mixtures ${ }^{[28,29]}$, in which the data is used derives from four linear regression calibration equations, two calibrations for each component at two wavelengths selected using the method of Kaiser ${ }^{[30]}$, whichwas used for the selection of optimum wavelength set which assured the best sensitivity for the quantitative determination of the studied drug In order to apply this method, the signals GEM and its acid degradation products located at six wavelengths: $255.0,270.0,277.0,310.0,320.0$, and $340.0 \mathrm{~nm}$ were selected. 
The determinants of these matrices were calculated as shown in Table (1). The wavelength set (255.0 and 277.0) nm was selected for which the highest matrix determinant value was obtained.

Table (2) showed the linear regression calibration formula used for bivariate algorithm.

\subsection{Method validation}

Method validation is an integral part of the analytical procedure; therefore full validation study was done for each proposed method. Analytical figures of merits were applied in agreement with $\mathrm{ICH}$ guidelines ${ }^{[31]}$ by measuring range, accuracy, precision, repeatability, interday precision, linearity, application of dosage form, application of standard addition technique and specificity. Results obtained are depicted in Tables (3-5).

\section{CONCLUSION:}

The proposed methods are accurate, precise and reproducible. They are stability-indicating methods. These methods complied with the validation guidelines of the International Conference on Harmonization and could be used for purity testing, stability studies, quality control, and routine analysis of GEM either in its bulk powder or in dosage form without noticeable interference from other common dosage form additives. The obtained results were statistically non-significant when they have been compared with those of the reference method.

Table 1: Application of the method of Kaiser for the selection of the wavelength set for the determination of GEM.

\begin{tabular}{|c|c|c|c|c|c|c|}
\hline$\lambda_{1} / \boldsymbol{\lambda}_{2}$ & $\mathbf{2 5 5 . 0}$ & $\mathbf{2 7 0 . 0}$ & $\mathbf{2 7 7 . 0}$ & $\mathbf{3 1 0 . 0}$ & $\mathbf{3 2 0 . 0}$ & $\mathbf{3 4 0 . 0}$ \\
\hline $\mathbf{2 5 5 . 0}$ & 0 & 1353.56 & $\mathbf{1 5 6 3 . 4 8}$ & -27.84 & 87.02 & 524.82 \\
\hline $\mathbf{2 7 0 . 0}$ & & 0 & 538.98 & -520.26 & -531.05 & -217.23 \\
\hline $\mathbf{2 7 7 . 0}$ & & & 0 & -589.86 & -648.06 & -459.9 \\
\hline $\mathbf{3 1 0 . 0}$ & & & & 0 & 44.37 & 206.19 \\
\hline $\mathbf{3 2 0 . 0}$ & & & & & 0 & 191.94 \\
\hline $\mathbf{3 4 0 . 0}$ & & & & & & 0 \\
\hline
\end{tabular}

Table 2 : Linear regression calibration formulae used for the bivariate algorithm.

\begin{tabular}{|l|l|l|}
\hline Component & \multicolumn{2}{l|}{ Calibration equations } \\
\hline & $\lambda_{1}=255.0 \mathrm{~nm}$ & $\lambda_{2}=277.0 \mathrm{~nm}$ \\
\hline Gemifloxacin & $\begin{array}{l}\mathrm{A}=0.0500 \mathrm{C}+0.0163 \\
\mathrm{r}=0.9992 .\end{array}$ & $\begin{array}{l}\mathrm{A}=0.0822 \mathrm{C}-0.0378 \\
\mathrm{r}=0.9992\end{array}$ \\
\hline Acid degradation products & $\begin{array}{l}\mathrm{A}=0.0234 \mathrm{C}+0.0151 \\
\mathrm{r}=0.9992\end{array}$ & $\begin{array}{l}\mathrm{A}=0.0072 \mathrm{C}+0.0041 \\
\mathrm{r}=0.9997\end{array}$ \\
\hline
\end{tabular}

$A=$ Absorbance at the selected wavelength.

$\mathrm{C}=$ Concentration in $\mu \mathrm{g} \mathrm{mL} \mathrm{L}^{-1} . \quad \mathrm{r}=$ Correlation coefficient. 


\section{ISSN 2321-807X}

Table 3: Results of validation parameters of the responses and the regression equations obtained by the proposed methods

\begin{tabular}{|c|c|c|c|c|c|c|c|c|}
\hline \multirow{2}{*}{\multicolumn{2}{|c|}{ Validation parameters }} & \multirow{2}{*}{$\begin{array}{l}D^{1} \text {-method } \\
254.6 \mathrm{~nm}\end{array}$} & \multicolumn{2}{|c|}{ 'DD-method } & \multirow{2}{*}{$\begin{array}{l}\text { Dual- } \\
\text { wavelength } \\
\text { method }\end{array}$} & \multirow{2}{*}{$\begin{array}{l}\text { Ratio-difference } \\
\text { method }\end{array}$} & \multicolumn{2}{|c|}{ Bivariate method } \\
\hline & & & $273.0 \mathrm{~nm}$ & $284.0 \mathrm{~nm}$ & & & $255.0 \mathrm{~nm}$ & $277.0 \mathrm{~nm}$ \\
\hline \multicolumn{2}{|c|}{ Accuracy ( mean $\pm \%$ RSD) } & $\begin{array}{l}99.67 \pm \\
0.799\end{array}$ & $\begin{array}{l}99.91 \pm \\
0.829\end{array}$ & $100.01 \pm 0.304$ & $\begin{array}{c}100.29 \pm \\
1.107\end{array}$ & $99.97 \pm 0.637$ & \multicolumn{2}{|c|}{$99.87 \pm 1.254$} \\
\hline \multicolumn{2}{|c|}{ Specificity $\pm \%$ RSD } & $\begin{array}{l}99.67 \pm \\
0.689\end{array}$ & $\begin{array}{l}100.32 \\
\pm 0.796\end{array}$ & $99.75 \pm 0.730$ & $99.53 \pm 0.399$ & $101.23 \pm 1.360$ & \multicolumn{2}{|c|}{$100.14 \pm 1.533$} \\
\hline \multicolumn{2}{|r|}{ Range $\left(\mu \mathrm{g} \mathrm{mL} L^{-1}\right)$} & \multicolumn{7}{|c|}{$2.0-12.0$} \\
\hline & Slope & 0.0585 & 0.0767 & 0.1014 & 0.0581 & 0.7113 & 0.0500 & 0.0822 \\
\hline & Intercept & 0.0142 & -0.0629 & -0.0656 & -0.0253 & 0.0927 & 0.0163 & -0.0378 \\
\hline \multicolumn{2}{|c|}{ Correlation coefficient ( $r$ ) } & 0.9997 & 0.9994 & 0.9996 & 0.9998 & 0.9996 & 0.9996 & 0.9996 \\
\hline \multirow{2}{*}{$\begin{array}{l}\frac{0}{0} \\
\frac{0}{0} \\
\frac{d}{2}\end{array}$} & Repeatability* & 0.381 & 0.276 & 0.720 & 0.215 & 0.562 & \multicolumn{2}{|c|}{1.102} \\
\hline & $\begin{array}{l}\text { Intermediate } \\
\text { Precision }{ }^{\star \star}\end{array}$ & 0.714 & 1.072 & 0.924 & 0.326 & 1.247 & \multicolumn{2}{|c|}{1.241} \\
\hline & $O D\left(\mu g \cdot m L^{-1}\right)^{\star \star \star}$ & 0.282 & 0.425 & 0.348 & 0.253 & 0.325 & \multicolumn{2}{|c|}{$\begin{array}{l}\lambda_{1}=0.356, \lambda_{2} \\
=0.355\end{array}$} \\
\hline & $\mathrm{OQ}\left(\mu \mathrm{g} \cdot \mathrm{mL}^{-1}\right)^{\star \star \star}$ & 0.853 & 1.288 & 1.053 & 0.765 & 0.984 & \multicolumn{2}{|c|}{$\lambda_{1}=1.078, \lambda_{2}=1.076$} \\
\hline
\end{tabular}

*The intraday $(n=9)$, average of three different concentrations repeated three times within the day.

**The interday $(n=9)$, average of three different concentrations repeated three times in three successive days.

*** Limit of detection and quantitation are determined via calculations, LOD $=(\mathrm{SD}$ of the response/slope $) \mathrm{X} 3.3 ; \mathrm{LOQ}=(\mathrm{SD}$ of the response/slope) $\times 10$

Table 4 : Determination of the studied drug in the laboratory prepared (L.P.) mixtures with its degradation products and in tablets by the proposed methods.

\begin{tabular}{|c|c|c|c|c|c|c|}
\hline \multirow{2}{*}{ Sample } & \multirow{2}{*}{$\begin{array}{l}D^{1}-\text { method } \\
(n=6)^{b}\end{array}$} & \multicolumn{2}{|r|}{${ }^{1}$ DD-method } & \multirow{2}{*}{$\begin{array}{l}\text { Dual } \\
\text { wavelength } \\
\text { Method }(n=6)^{b}\end{array}$} & \multirow{2}{*}{$\begin{array}{l}\text { Ratiodifferencemet } \\
\operatorname{hod}(n=6)^{b}\end{array}$} & \multirow{2}{*}{$\begin{array}{l}\text { Bivariate calibration } \\
\text { method } \\
(n=8)^{b}\end{array}$} \\
\hline & & $273 n m(n=8)^{b}$ & $284 n m(n=7)^{b}$ & & & \\
\hline $\begin{array}{l}\text { L.P. mixtures } \\
\qquad(\text { Mean } \pm \text { SD) }\end{array}$ & $99.67 \pm 0.687$ & $100.32 \pm 0.799$ & $99.75 \pm 0.728$ & $99.53 \pm 0.397$ & $101.23 \pm 1.363$ & $100.14 \pm 1.535$ \\
\hline $\begin{array}{l}\text { Factive }{ }^{\circledR} \text { tablet } \\
\text { BN:005 } \\
\text { ( Mean } \pm \% \text { RSD) }\end{array}$ & $\begin{array}{l}100.21 \pm \\
1.178\end{array}$ & $\begin{array}{c}100.10 \pm \\
1.941\end{array}$ & $100.29 \pm 1.917$ & $99.03 \pm 0.893$ & $99.73 \pm 1.895$ & $99.15 \pm 1.349$ \\
\hline $\begin{array}{l}\text { Standard addition } \\
\text { (Mean } \pm \% \text { RSD) }\end{array}$ & $100.66 \pm 1.010$ & $99.51 \pm 1.221$ & $100.04 \pm 1.131$ & $99.96 \pm 1.116$ & $99.40 \pm 0.817$ & $100.21 \pm 1.593$ \\
\hline
\end{tabular}

\footnotetext{
${ }^{b}$ Sets each of 3 replicates
} 


\section{ISSN 2321-807X}

Table 5 : Statistical comparison of the results obtained by the proposed methods and the reported method for the determination of Gemifloxacin in pharmaceutical preparation.

\begin{tabular}{|c|c|c|c|c|c|c|c|}
\hline \multirow{2}{*}{ Item } & \multirow{2}{*}{$\begin{array}{c}D^{1}- \\
\text { method }\end{array}$} & \multicolumn{2}{|c|}{${ }^{7}$ DD-method } & \multirow{2}{*}{$\begin{array}{c}\text { Dual } \\
\text { wavelength } \\
\text { method }\end{array}$} & \multirow{2}{*}{$\begin{array}{l}\text { Ratio difference } \\
\text { method }\end{array}$} & \multirow{2}{*}{$\begin{array}{l}\text { Bivariate } \\
\text { calibration } \\
\text { method }\end{array}$} & \multirow{2}{*}{$\begin{array}{c}\text { Reported } \\
\text { method } \\
\star \star\end{array}$} \\
\hline & & $273.0 \mathrm{~nm}$ & $284.0 \mathrm{~nm}$ & & & & \\
\hline Mean & 99.67 & 99.91 & 100.01 & 100.29 & 99.97 & 99.87 & 99.61 \\
\hline SD & 0.796 & 0.828 & 0.304 & 1.110 & 0.637 & 1.252 & 0.579 \\
\hline \%RSD & 0.799 & 0.829 & 0.304 & 1.107 & 0.637 & 1.254 & 0.581 \\
\hline $\mathbf{n}$ & 6 & 6 & 6 & 6 & 6 & 6 & 6 \\
\hline Variance & 0.634 & 0.686 & 0.092 & 1.232 & 0.406 & 1.568 & 0.335 \\
\hline $\begin{array}{l}\text { Student's } t \text {-test } \\
(2.228)\end{array}$ & 0.149 & 0.728 & 1.498 & 1.331 & 1.026 & 0.462 & \\
\hline F-test $(5.050)$ & 1.89 & 2.05 & 3.64 & 3.68 & 1.21 & 4.73 & \\
\hline
\end{tabular}

${ }^{*}$ Figures in parenthesis are corresponding theoretical $t$ - and $F$ - values at $p=0.05{ }^{(4)}$

** UV-Spectrophotometric method; a methanolic solution of Gemifloxacin was scanned between (200-400 nm), measured at $263.8 \mathrm{~nm}^{[4]}$.

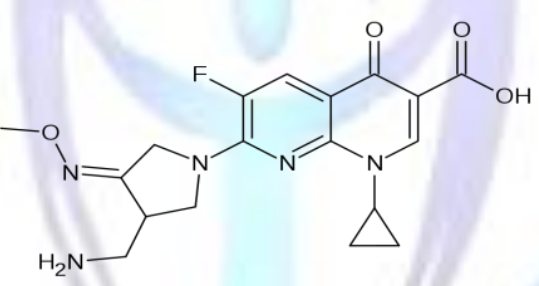

Figure 1: Chemical structure of intact Gemifloxacin.<smiles>CO/N=C1\CN(c2nc3c(cc2F)c(=O)c(C(=O)O)cn3C2CC2)CC1CN</smiles>

Intact GEM

$389.38 \mathrm{~m} / \mathrm{z}$

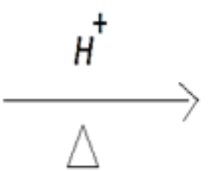

GEM acid degradate (l)

$220.21 \mathrm{~m} / \mathrm{z}$<smiles>C[I+]C1CNCC1CN</smiles>

GEM acid degradate (II)

$143.19 \mathrm{~m} / \mathrm{z}$

Scheme 1 : The expected scheme of acid degradation of Gemifloxacin. 


\section{ISSN 2321-807X}

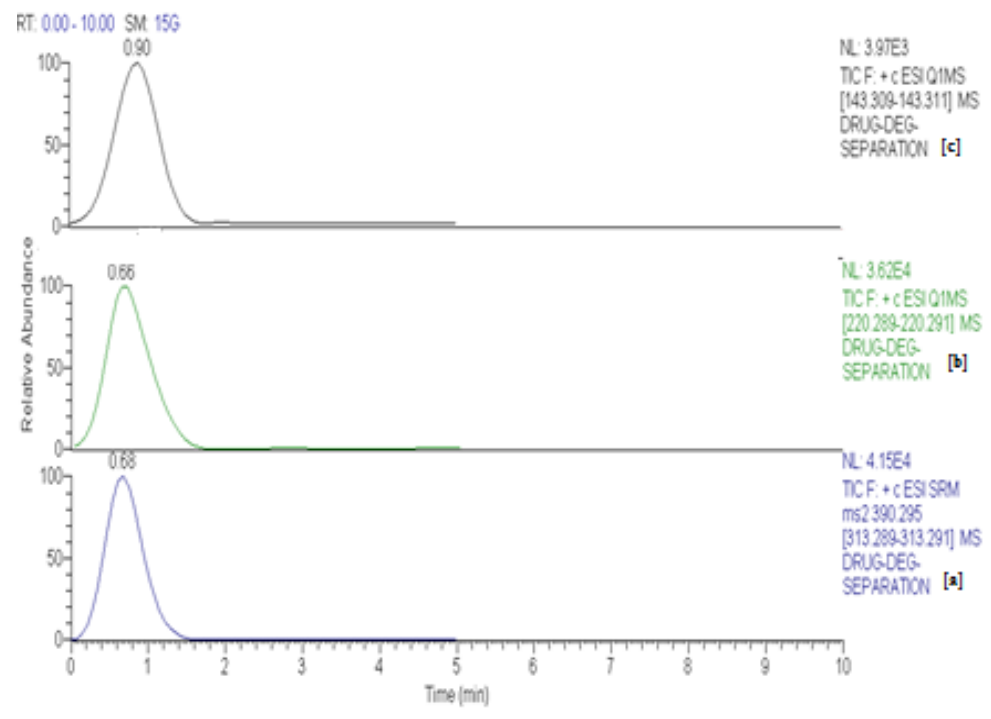

Figure 2 : Chromatogram of LC/MS determination of GEM in presence of its acid degradation products, [a] for pure GEM, [b] for degradation product (I) and [c] for degradation (II).

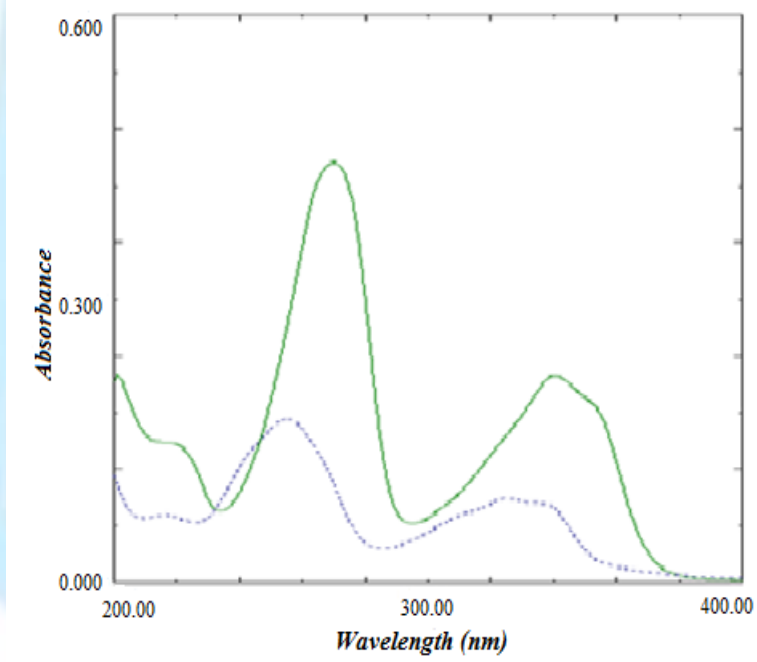

Figure 3 : Zero-order spectra of $5 \mu \mathrm{g} \cdot \mathrm{mL}^{-1}$ pure GEM (_ ) and $5 \mu \mathrm{g} \cdot \mathrm{mL}^{-1}$ acid degradation products (- - - -), using methanol as a solvent.

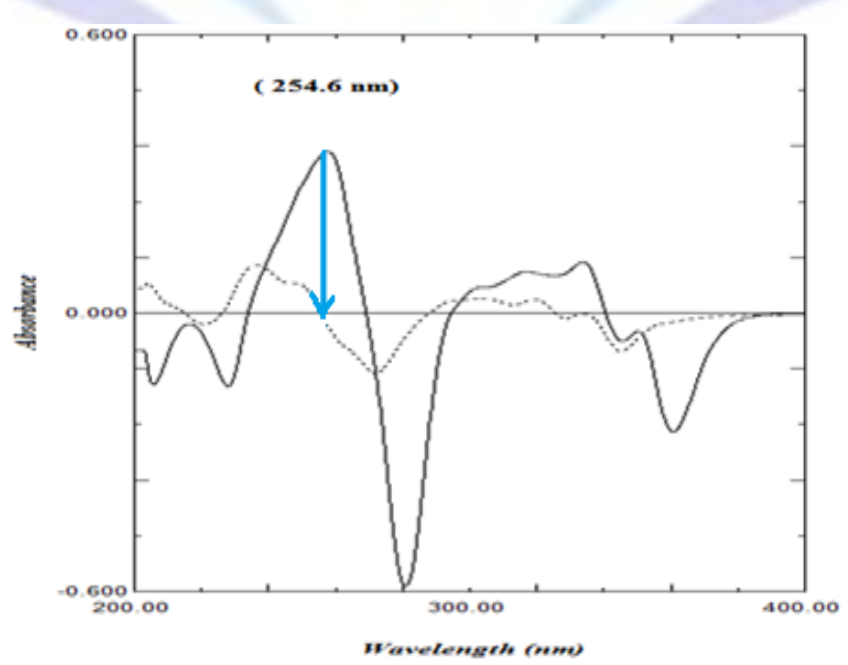

Figure 4 : First derivative absorption spectra of GEM (__ ) and acid degradation products (- - - -), concentration of each is $6 \mu \mathrm{g} \mathrm{mL}^{-1}$ using methanol as a solvent. 


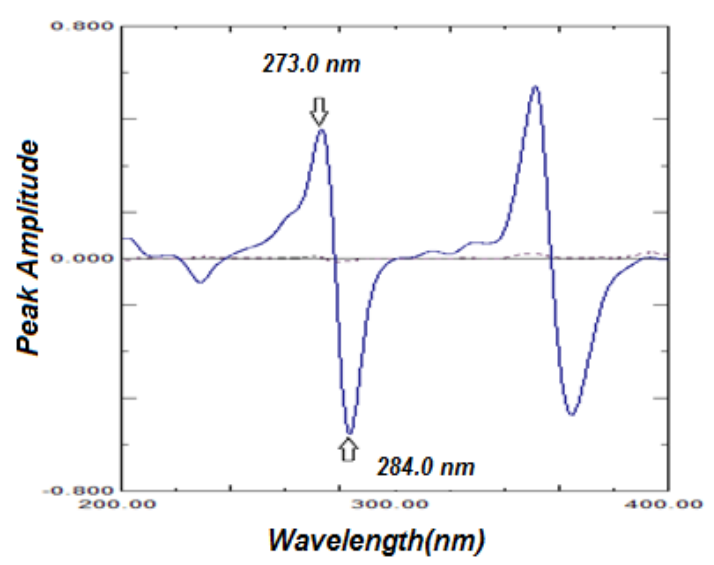

Figure 5 : ' $D$ D-Ratio spectra of intact GEM (A) and GEM acid degradation products (B) using a spectrum of $8 \mu \mathrm{g}$ $\mathrm{mL}^{-1}$ of its degradation product as a divisor, concentration of each is $6 \mu \mathrm{g} \mathrm{mL}^{-1}$.

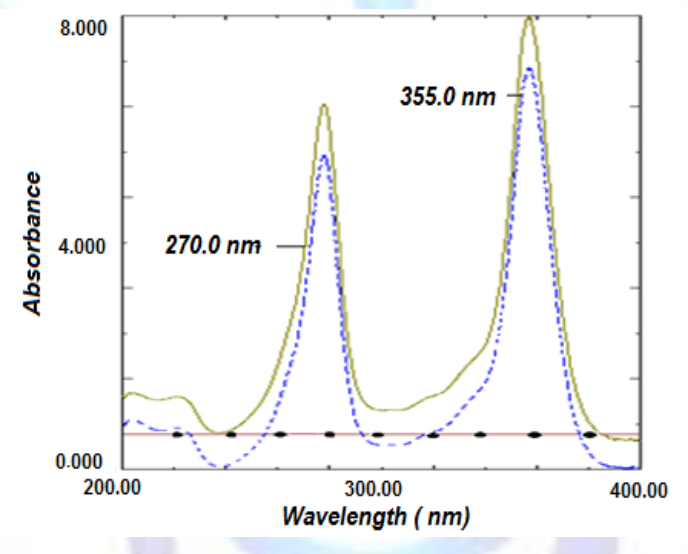

Figure 6 : The ratio spectrum of $5 \mu \mathrm{gL} \mathrm{m}^{-1}$ intact GEM ( $\left.\_\right), 8 \mu \mathrm{g} \mathrm{mL} \mathrm{L}^{-1} \mathrm{GEM}$ acid degradation products( $\left.\bullet \bullet \bullet-\right)$ and a mixture containing $5 \mu \mathrm{g} \mathrm{mL}^{-1}$ intact GEM and $5 \mu \mathrm{g} \mathrm{mL}-1$ acid degradates (- - - ) using a divisor of $8 \mu \mathrm{g} \cdot \mathrm{mL}^{-1}$ degradates in methanol.

\section{REFERENCES:}

1. Merck index, an encyclopedia of chemicals, drugs and biological, fourteenth edition, USA, 2006.

2. www.drugbank.ca/drugs/DB01155 \#pharmacology 15March2015.

3. S.C. Sweetman, Martindale (The complete drug reference), Thirty -seventh edition, the pharmaceutical press, London 2011.

4. R Rote AMBADAS; P.PINGLE SUNITA; E-Journal of Chemistry 2010,7(S1),S344-S348.

5. Akram M. El-Didamony, Mona O. Abo-Elsoad Journal of Saudi Chemical Society, In Press, Corrected Proof, Available online 21 October 2013.

6. Paim, C. S.; Fuhr, F.; Miron, D. S.; Steppe, M.; Schapoval, E. E. S.*; . Journal of AOAC International, 2014,97 (1), 94-98.

7. Gouda, A. A.*; Amin, A. S.; El-Sheikh, R.; Yousef, A. G.; Journal of Analytical Methods in Chemistry, 2014, 2014 (1), 286379.

8. Zhong, W. Y.*; Wang, Y.; Huang, B.; Shu, C.; Guangpuxue Yu GuangpuFenxi, 2012, 32 (06), 1570-1574.

9. Roy, B.; Das, A.; Bhaumik, U.; Sarkar, A. K.; Bose, A.; Mukharjee, J.; Chakrabarty, U. S.; Das, A. K.; Pal, T. K., Journal of Pharmaceutical and Biomedical Analysis, 2010, 52 (2), 216-226.

10. Doyle, E.; Fowles, S. E.; McDonnell, D. F.; McCarthy, R.; White, S. A.; Journal of Chromatography, B: Biomedical Applications, 2000, 746 (2), 191-198. 


\section{ISSN 2321-807X}

11. Szultka, M.; Krzeminski, R.; Walczak, J.; Jackowski, M.; Buszewski, B., Biomedical Chromatography, 2014,28 (2), 255-264.

12. Raju, B.; Ramesh, M.; Borkar, R. M.; Padiya, R.; Banerjee, S. K.*; Srinivas, R., Biomedical Chromatography, 2012 , $26(11), 1341-1347$.

13. Robledo, V. R. and Smyth, W. F., AnalyticaChimicaActa, 2008, 623 (2), 221-230

14. Rote, A. R.*; Pingle, S. P., Journal of Chromatography, B: Analytical Technologies in the Biomedical and Life Sciences, 2009, 877 (29), 3719-3723.

15. de Araujo, B. V.; Laureano, J. V.; Grunspan, L. D.; Costa, T. D.; Tasso, L.*; Journal of Chromatography, B: Analytical Technologies in the Biomedical and Life Sciences, 2013, 919-920 (1), 62-66.

16. Rao, R. N.*; Naidu, C. G.; Prasad, K. G.; Padiya, R.; Agwane, S. B.; HPLC Group, Analytical Chemistry Division, Discovery Laboratory Indian Institute of Chemical Technology, Source: Biomedical Chromatography, 2012,26 (12), 1534-1542.

17. Grunspan, L. D.; Kaiser, M.; Hurtado, F. K.; Costa, T. D.; Tasso, L. *:Laboratorio de Famacologia e Fisiologia, Curso de FarmaciaUniversidade de Caxias do Sul, Chromatographia, 2012, 75 (5-6), 253-262.

18. Kaiser, M.; Grunspan, L. D.; Costa, T. D.; Tasso, L.*; Curso Farm., Lab. Fisiol. Farmacol. UCS, 95020-972, Caxias do Sul, RS, Brazil, Journal of Chromatography, B: Analytical Technologies in the Biomedical and Life Sciences, 2011, 879 (30), 3639-3644.

19. Rao, R. N.*; Naidu, C. G.; Prasad, K. G.; Narasimha, R.; Anal. Chem. Div. Indian Inst. Chem. Technol., Tarnaka, Hyderabad, 500 607, India Source: Biomedical Chromatography, 2011, 25 (11), 1222-1229.

20. Al-Hadiya, B. M. H.*; Khady, A. A.; Mostafa, G. A. E.; Talanta, 2010, 83 (1), 110-116.

21. Ranjane, P. N.; Gandhi, S. V.*; Kadukar, S. S.; Bothara, K. G.; Chromatographia, 2010,71 (11-12), 1113-1117.

22. Hyun, M. H.; Han, S. C.; Cho, Y. J.; Jin, J. S.; Lee, W. J., Biomedical Chromatography, 2002, 16 (5), 356-360.

23. Lee, W. J.; Hong, C. Y., Journal of Chromatography, 2000, 879 (2), 113-120.

24. Hyun, M. H. and Han, S. C. Journal of Biochemical and Biophysical Methods, 2002, 54, (1-3), 235-243.

25. Choi, H. J.; Cho, H. S.; Han, S. C.; Hyun, M. H., Journal of Separation Science, 2009, 32 (4), 536-541.

26. P. Campins-Falco, F.Blasco Go Mez and F.bosch-Reig; Talanta,47,193-202(1998).

27. Eman S. ElZanfaly, Ahmed S.Saad, AbdElaziz B. AbdElaleem; Journal Of Pharmaceutical analysis, Volume 2, Issue 5, 382-385(October 2012)

28. Lopez-Martinez L., Lopez-de-Alb P.L., Creda-Martin V., (2001). Analytical letters, 34(14), 2563.

29. Lopez-de-Alba P.L., Wrobel K., Lopez-Martinez L., Yepez-Murrieta M.L. , Amador-Hernandez J.,(1997). Journal of pharmaceutical \&Biomedical Analysis, 16, 349.

30. Massart D.L., Vandeginsite B.G.M., Deming S.N., Michotte Y., Kaufman L., (1988).Chemometrics: a textbook, ElServier , Amsterdam, pp.124.

31. International Conference on Harmonization (ICH). ICH Harmonized Tripartite Guideline. Topic Q2(R1). Validation of Analytical Procedures: Text and Methodology; Geneva, Switzerland.( 2005). 


\section{Author's Biography:}

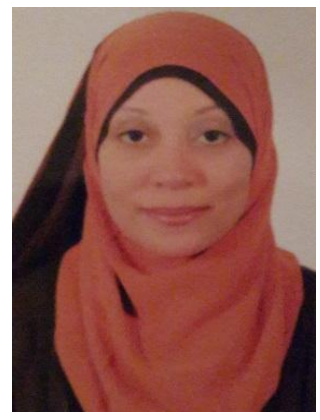

Fatma Mahmoud is a quality assurance supervisor at VACSERA holding company for biological products and vaccines since 2003. She received the Bachelor degree in pharmaceutical sciences from Cairo University, Egypt, in 2002. Her main areas of research are in Analytical chemistry and pharmaceutical products quality control.

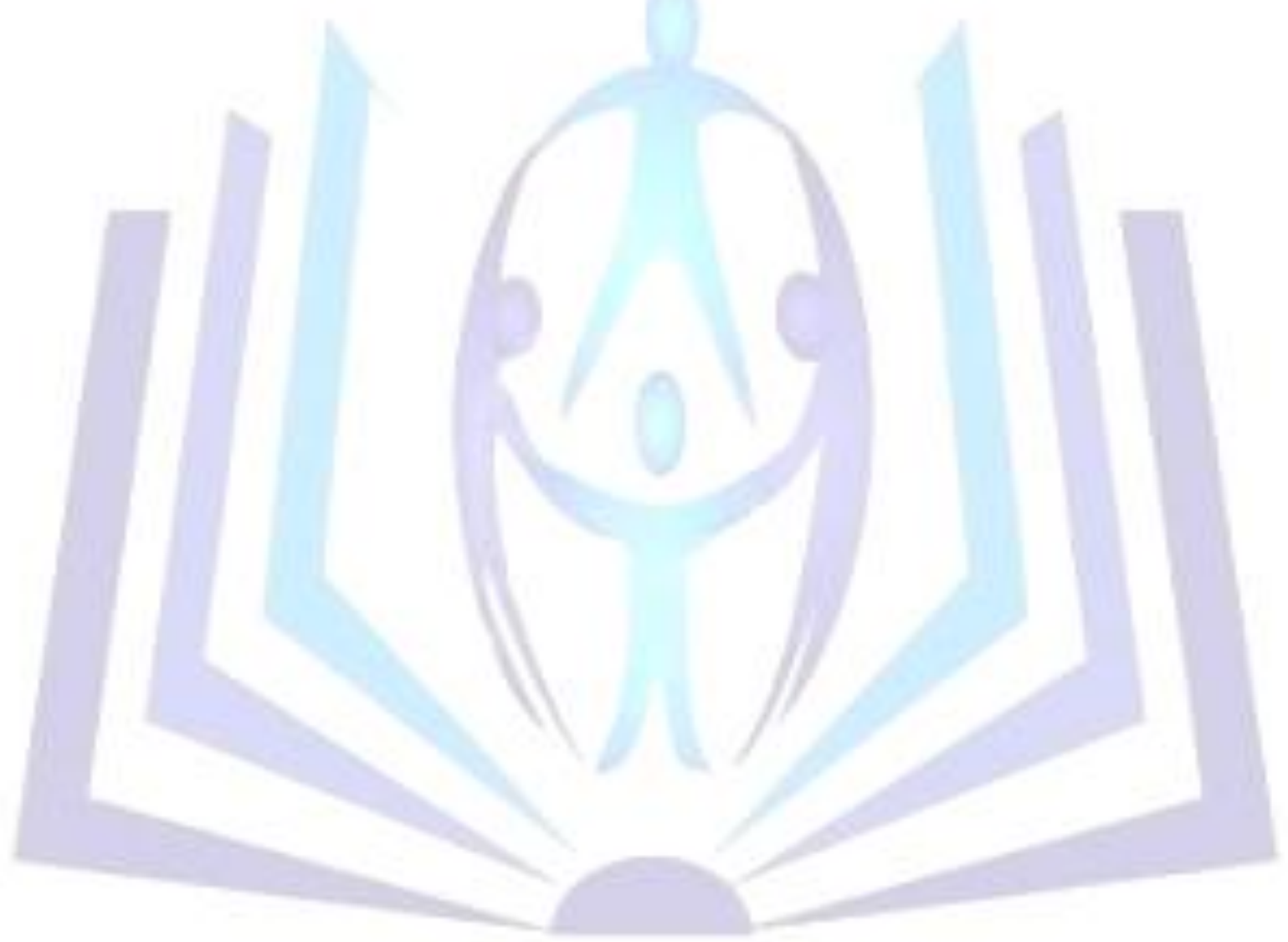

